\title{
Cellular Oxidant/Antioxidant Network: Update on the Environmental Effects Over Marine Organisms
}

\author{
Paula M. González, Gabriela Malanga and Susana Puntarulo* \\ Physical Chemistry-Institute of Biochemistry and Molecular Medicine (IBIMOL), School of Pharmacy and \\ Biochemistry, University of Buenos Aires-CONICET, Buenos Aires, Argentina
}

\begin{abstract}
Aquatic organisms are exposed and adjust to a wide variety of environmental challenges including natural and anthropogenic factors. Natural sources are understood the effects of temperature, and saline fluctuations, oxygen availability, the relative abundance of chemical elements and pathogenic invasion. On the contrary, anthropogenic factors are considered the availability of heavy metals, the presence of hydrocarbons, industrial and urban wastes, and pesticides. Moreover, these organisms suffer, in order to maintain homeostasis, growth and reproduction, the effect of temporal and spatial variations. All the environmental changes (natural and non-natural) may cause a different degree of stress in aquatic organisms, via induction of disbalance between the generation and elimination of reactive oxygen species and reactive nitrosative species. A brief summary on the actual knowledge on the establishment, by environmental effects, of oxidative/nitrosative stress and the effect on the antioxidant system in marine organisms, is presented in this review to contribute to the deeper understanding of the complexity of the metabolic and physiological changes that aquatic organisms are constantly suffering.
\end{abstract}

Keywords: Anthropogenic environmental changes, natural environmental changes, marine organisms, nitrosative stress, oxidative stress, reactive oxygen species.

\section{INTRODUCTION}

Aquatic organisms are exposed and adjust to a wide variety of environmental challenges including natural and anthropogenic factors (Fig. 1). Water bodies and oceans receive increased number of pollutants that could be uptaken by different species from water, sediments, suspended particulate matter, and food sources [1]. Water pollution type and level can be accurately identified by analyzing the species, amounts, physiological and biological responses and residue contents. All the environmental changes (natural and non-natural) may cause a different degree of stress in aquatic organisms, via induction of disbalance between the generation and elimination of reactive oxygen species (ROS) and reactive nitrosative species (RNS).

Among the feasible organisms actually chosen for pollution monitoring, aquatic algae, molluses and fishes are the mostly used. The uptake of xenobiotic by phytoplankton is the first step in the bioaccumulation in aquatic food webs. The aquatic algae, important elementary producers in marine and inland water, play a key role to the whole ecosystem, since the type of species and their amount can even reflect the water quality. Molluscs, like bivalves and limpets, are considered key organisms for environmental monitoring based on their wide geographical distributing, abundance, type of movement (sedentary or mobile), tolerance to

*Address correspondence to this author at the Fisicoquímica-IBIMOL, Facultad de Farmacia y Bioquímica, Junín 956 (C1113AAD) Buenos Aires, Argentina; Phone: 5411-4964-8244; Fax: 5411-4508-3646;

E-mail: susanap@ffyb.uba.ar environmental (natural and contaminants) alterations, their ability to concentrate pollutants, the level of metabolizing enzyme activities of organic contaminants, the nature of the populations, the life span and size, and the potential to survive in laboratory and field studies in cages [2]. Fishes are generally used for pollution monitoring because not only can be found virtually everywhere in the aquatic environment but also play a major ecological role in aquatic food webs because of their function as carriers of energy from lower to higher trophic levels [3]. Among the wide array of functions selected to assess the effect of pollution in these organisms, oxidative status is one of the most studied.

A brief summary on the actual knowledge (see Pinto et al. [4] and Lushchak [1] for previous reviews on the subject) on the establishment in marine organisms of oxidative/nitrosative stress and antioxidant capacity associated to environmental effects, is presented in this review to contribute to a deeper understanding of the complexity of the metabolic and physiological changes that aquatic organisms are constantly suffering.

\section{GENERAL FEATURES OF OXIDATIVE/NITROSA- TIVE METABOLISM AND ANTIOXIDANT CAPA-CITY IN MARINE ORGANISMS}

Basically, pro- and antioxidant processes are the same across marine invertebrates and mammalian systems. However, the specific conditions for radical formation, a key feature in stress physiology and aging, are different and highly variable among aquatic cold blooded organisms [5]. ROS include superoxide anion $\left(\mathrm{O}_{2}^{-}\right)$, hydroxyl radical $\left({ }^{\circ} \mathrm{OH}\right)$, 


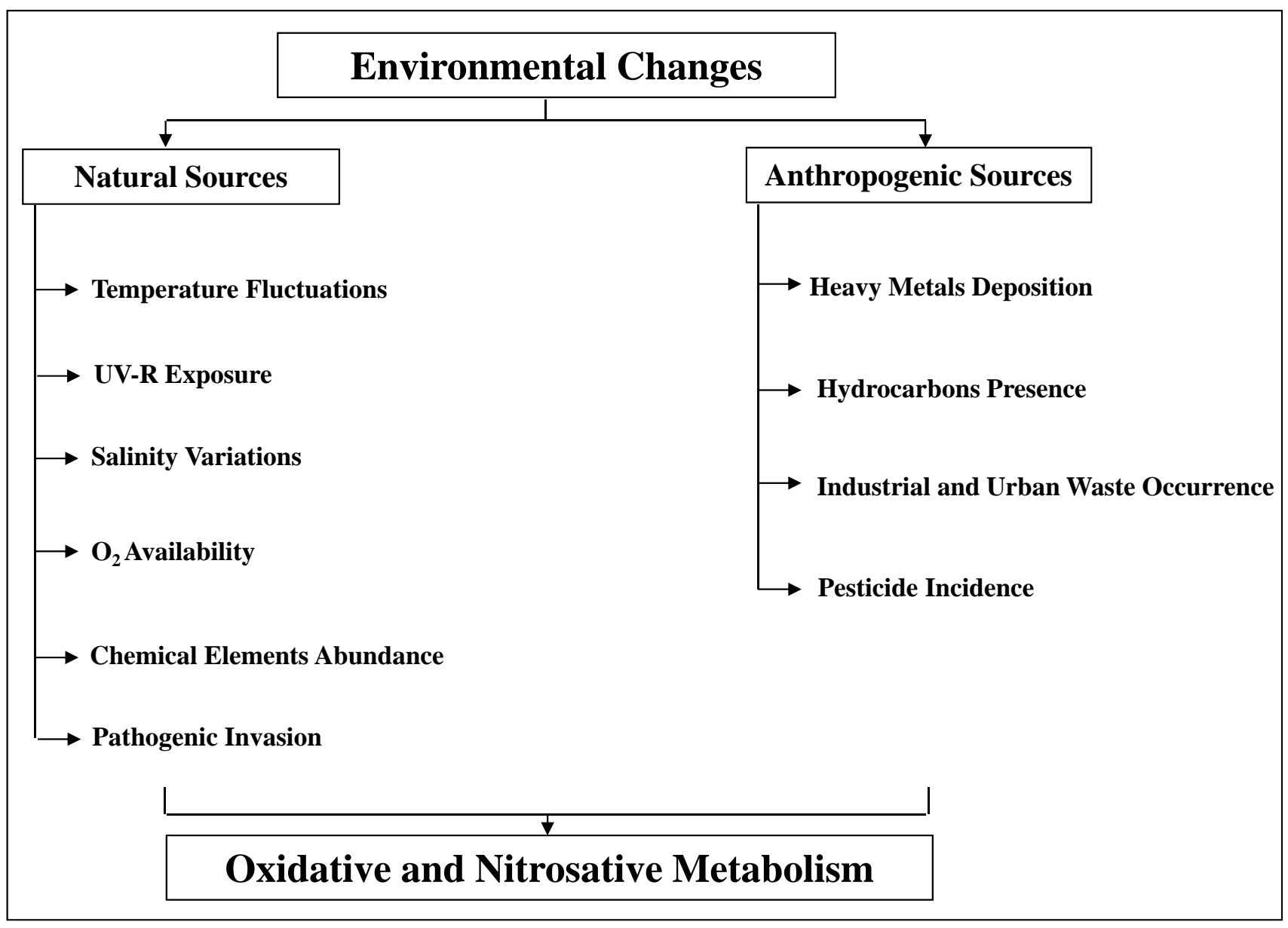

Fig. (1). General diagram showing the environmental changes, both natural and anthropogenic, influencing the settlement of oxidative and nitrosative stress condition in marine organisms.

hydrogen peroxide $\left(\mathrm{H}_{2} \mathrm{O}_{2}\right)$, singlet oxygen $\left({ }^{1} \mathrm{O}_{2}\right)$, and peroxyl radicals. ROS are highly reactive oxidants and mainly regarded as hazardous species whose production in cellular and extracellular systems has to be tightly controlled by antioxidants and radical scavenging biochemical reactions. However, recently it has been recognized the importance of radical species in cellular signaling and in the maintenance of homeostatic conditions. Moreover, some radicals, such as the very short-lived and extremely hazardous ${ }^{\circ} \mathrm{OH}$, are still regarded as highly reactive and dangerous, but many other more stable species have been postulated as signaling molecules in cellular growth, or as oxidants that assure an appropriate oxidation state of cellular compartments and the biochemical structures and elements they contain [6]. According to the present view, a basal amount of ROS is formed at all times in all aerobic cells, and the steady state concentration of ROS in each cell (or compartment) depends on the formation rate of the radical (being mitochondria one of the most important intracellular radical sources), its reactivity and the concentration of available reaction partners. On the other hand, besides the bound $\mathrm{Fe}$, there is a fraction of the total cellular $\mathrm{Fe}$ content called the labile $\mathrm{Fe}$ pool (LIP). The LIP is experimentally defined as a lowmolecular-weight pool of weakly chelated Fe that is involved in a dynamic flux of solutes passing rapidly through the cell. The LIP is assumed to consist of both forms of ionic $\mathrm{Fe}\left(\mathrm{Fe}^{2+}\right.$ and $\mathrm{Fe}^{3+}$ ) bound to citrate and other organic ions, phosphates (ATP, AMP), carbohydrates and carboxylates, nucleotides and nucleosides, polypeptides, and phospholipids [7]. Besides the importance of this readily available $\mathrm{Fe}$ for cellular growth and metabolism, the LIP (also defined as the source for catalytically active available $\mathrm{Fe}$ in the cells) is held responsible for the generation of extremely reactive species, such as ${ }^{\circ} \mathrm{OH}[8]$.

Nitric oxide (NO) is recognized both, as a signaling molecule that regulates many enzyme activities, but as a toxic agent as well. It has been found that NO is able to protect all cell types from oxidative damage resulting from $\mathrm{O}_{2}^{-}, \mathrm{H}_{2} \mathrm{O}_{2}$ and alkyl peroxides by acting as a terminator of free radical chain reactions [9-12]. ROS and RNS interact through the reaction of $\mathrm{O}_{2}^{-}$with $\mathrm{NO}$, to generate peroxynitrite $\left(\mathrm{ONOO}^{-}\right)$at a velocity close to the diffusion rate. $\mathrm{ONOO}^{-}$acts as both, a nitrating agent and a powerful oxidant capable of modifying proteins (formation of nitrotyrosine), lipids (lipid oxidation, lipid nitration) and nucleic acids (DNA oxidation and DNA nitration) [13]. Besides being a regularly occurring radical intermediate of 


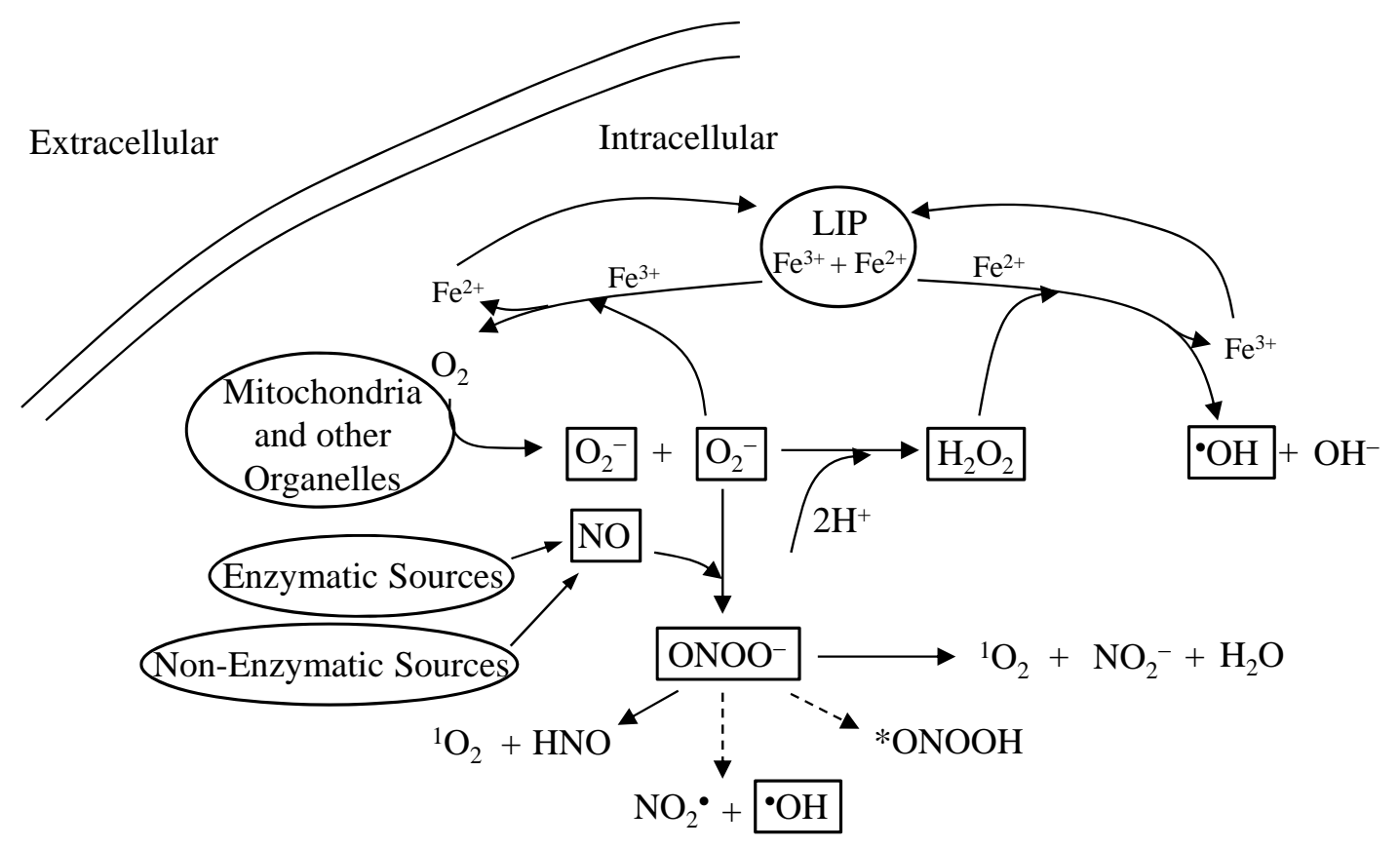

Fig. (2). Interaction between oxidative and nitrosative cellular networks.

many reactions, $\mathrm{NO}$ is also a molecule capable of binding $\mathrm{Fe}$ [14] and a highly diffusible second messenger that can elicit effects relatively far from its site of production. The concentrations, and the source of $\mathrm{NO}$, are the major factors determining its biological effects [15]. $\mathrm{NO}$ is mainly generated in mammalian cells and tissues from L-arginine by the activity of the enzyme nitric oxide synthase (NOS, EC 1.14.13.39) [16]. NOS-like enzymatic activity has been detected in marine, freshwater and terrestrial molluscs, including three gastropod subclasses (rosobranchs, opisthobranchs and pulmonates) [17], and in the bivalve Mya arenaria (Linnaeus) [18]. Fig. (2) summarizes the interaction among these chemical species in a cell.

To be able to maintain dangerous reactive species at low steady state concentrations the presence of many components are required to act as an adequate antioxidant defense system. The mechanisms for the action of these antioxidants involve three levels: (1) deactivation of reactive species. These antioxidants are either enzymatic (e.g. catalase, CAT; superoxide dismutase, SOD; glutathione peroxidase, GPx; glutathione reductase, GR) or nonenzymatic compounds, such as hydrophilic (e.g. reduced glutathione, GSH and ascorbic acid, $\mathrm{AH}^{-}$) and lipophilic (e.g. $\alpha$-tocopherol, $\alpha$-T) compounds; (2) prevention of radical formation [19]. At this level, proteins such as ferritin (Ft) (chelating $\mathrm{Fe}$ ) or ceruloplasmine (chelating $\mathrm{Cu}$ ) are considered important examples; (3) repair of already performed damage, such as the activity of DNA repairing enzymes [19]. Besides their individual actions, all these mechanisms interact among them in the intracellular environment (Fig. 3).

\section{EFFECT OF ENVIRONMENTAL CHANGES ON OXIDATIVE/NITROSATIVE STATUS AND ANTIO- XIDANT ABILITY OF MARINE ORGANISMS}

\subsection{Natural Sources}

Marine organisms withstand some of the harshest environmental conditions known, including freezing and heat stress, desiccation, salinity variations, carbon limitation, radiation in the intertidal regions. In addition, some areas suffer from $\mathrm{O}_{2}$ availability and also high chemical elements abundance from natural sources. All these factors may act together adding potentially stress to the marine biota (e.g. UV-B or temperature and salinity fluctuations). The environmental extremes also contribute to the photoinhibition of photosynthesis observed in ecologically important marine algae and to deleterious effects on the cellular metabolism [5].

\subsubsection{Temperature fluctuations}

Temperature fluctuations are known to affect all living organisms. With increasing atmospheric $\mathrm{CO}_{2}$ concentration, global temperature is expected to increase by the year 2100 in $2.5-6.4^{\circ} \mathrm{C}$ in the atmosphere [20], and by $2-3^{\circ} \mathrm{C}$ in the ocean surfaces [21]. Such changes will also have important effects on various organisms, since most physiological processes are temperature-dependent [22]. An increase of environmental temperature, which leads to metabolic activation, combined with an increase in $\mathrm{O}_{2}$ consumption initiates oxidative stress [23]. Long-term adaptations to high 


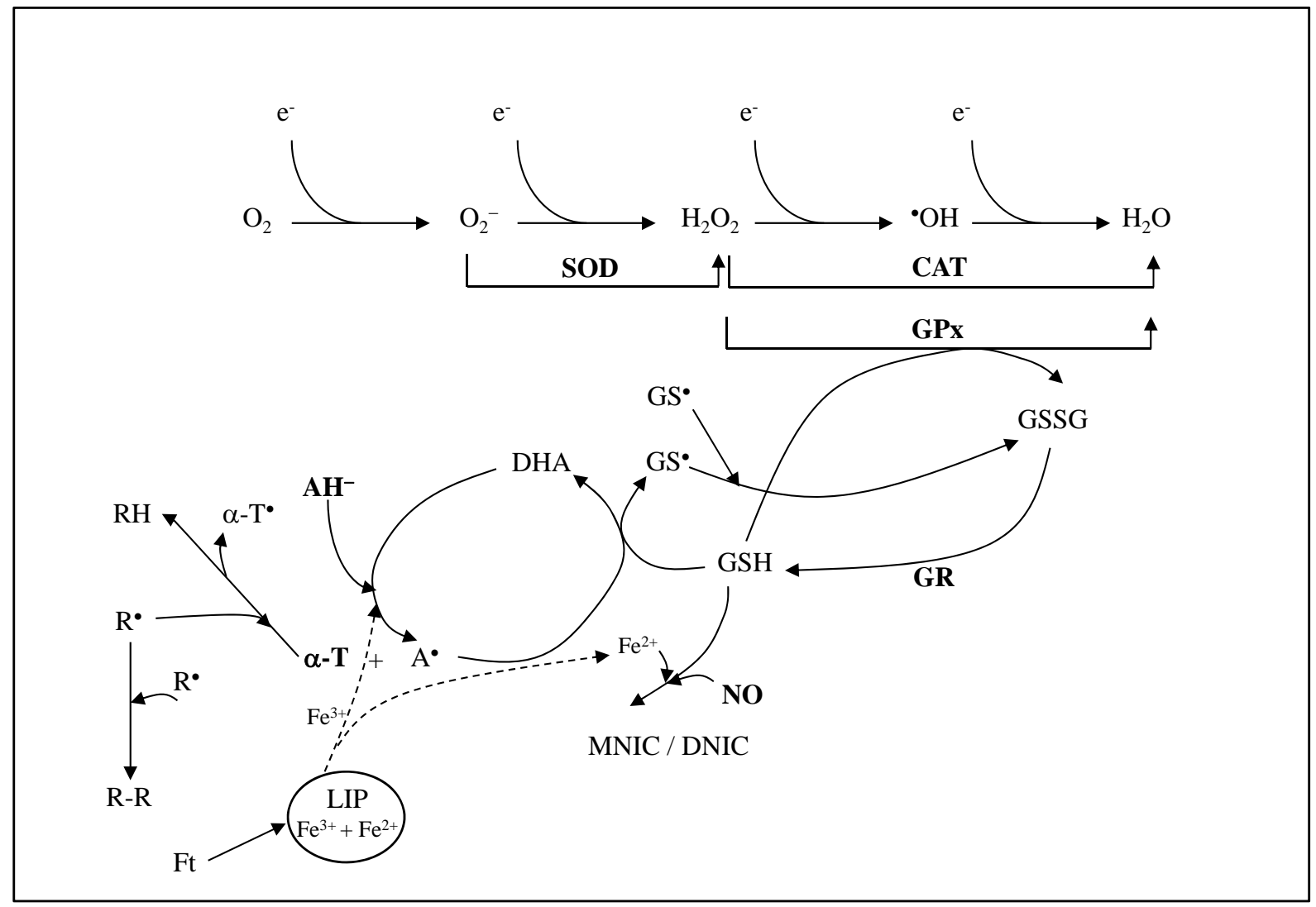

Fig. (3). General diagram of the cellular antioxidant network including enzymatic and non-enzymatic compounds. RH, membrane fatty acids; $\mathrm{R}^{*}$, lipid radicals; $\alpha-\mathrm{T}^{*}$, tocopheryl radical; $\mathrm{A}^{*}$, ascorbyl radical; DHA, dehydroascorbate; GS ${ }^{*}$ glutathione radicals. MNIC, mononytrosyl-Fe complexes; DNIC, dinytrosyl-Fe complexes.

temperatures result in crucial modifications of intermediary metabolism and cell membrane properties [24].

Ectotherms from permanently cold waters may be more susceptible to this stress and oxidative damage than organisms from other regions. This fact may be due to: i) $\mathrm{O}_{2}$ in cold waters and in corporal fluids presents more solubility than in temperate environments, and ii) invertebrates and polar fishes have lipidic membranes with a higher percentage of polyunsaturated fat acids that in the sustained life of free radicals at cold temperatures, may facilitate even more the propagation of lipid peroxidation reactions and extend the oxidative damage to tissues [25]. Elevated susceptibility of polar animals to oxidative stress would create a need to adjust antioxidant defense systems to function at low temperatures. A survey of antioxidant enzymes activities in polar and Mediterranean molluscs performed by Regoli et al. [26] supports this idea, since significantly higher SOD activities in gills of the Antarctic scallop Adamussium colbecki (Smith) were measured when compared to the Mediterranean bivalves Mytilus galloprovincialis (Lamarck) and Pecten jacobeus (Linnaeus). These authors also found higher activities for other antioxidant enzymes including CAT, GR, and GPx. However, this conclusion may not be valid for all tissues, since Regoli et al. [26] and Viarengo et al. [27] with the same polar scallop stock showed lower SOD activities in digestive gland of $A$. colbecki as compared to the Mediterranean scallops. Moreover, some enzymatic systems including antioxidant enzymes, like SOD, display temperature optimum curves with a maximal activity within the habitat temperature range in temperate ectotherms [28]. Snow and ice melt waters were shown to be extremely stressful for animals such as limpets, which clamp their shells down to the rock in order to avoid fresh water exposure [29]. Diversified responses to temperature fluctuations are expected in view of organism diversities in physiological pathways and ecological niches [30]. An essential adaptation to cold temperature involves biochemical compensation to the physiological functioning of cellular membranes. This adaptation is expressed by the production of low molecular weight lipids and the elaboration of higher levels of unsaturated and branchedchain fatty acids in the composition of cellular membranes [31]. However, achieving membrane functional homeostasis by increasing levels of lipid unsaturation occurs at the expense of enhancing the vulnerability of cellular membranes to oxidative damage. Thus, biochemical adaptation of cellular membranes to function at low-temperature affects a corresponding need for enhanced lipid-phase antioxidant protection, and this is demonstrated by the need for significantly dietary uptake of $\alpha$-T by coldwater teleost [32]. The biochemical selection for 'marine-derived' tocopherol (MDT) synthesis in cold-water marine producers may thus 
evolved to provide enhanced antioxidant protection for metabolic adaptation to low temperature [33]. The occurence of MDT in Antarctic notothenioids [34] is consistent with the finding of MDT in sub-polar fishes [33].

\subsubsection{UV Radiation (UV-R) Exposure}

Solar UV-R penetrates to ecological significant depths in aquatic systems and can affect from major biomass producers to consumers. Many factors influence the depth of penetration of radiation into natural waters including dissolved organic compounds, whose concentration and chemical composition are likely to be influenced by climate and UV-R variability. Organisms living in clear, shallow water are exposed to the damaging wavelengths of solar UV$\mathrm{R}$ coincident with the longer wavelengths of photosyntheticcally available radiation (PAR). Solar UV-B (280-315 nm) radiation at the Earth's surface has been shown to increase due to the ozone depletion and its interplay with climate change [35]. UV-A (315-400 nm) + UV-B is known to inhibit growth and photosynthesis [36-39] and to damage proteins and DNA [40-42]. However, moderate UV-R levels were shown to increase photosynthetic carbon fixation [43, 44], with UV-A even driving photosynthetic carbon fixation in the absence of PAR [45]. In marine systems, the absorption of solar radiation, and especially of its UV-R wavelengths, by dissolved organic matter in seawater leads to the photochemical production of diverse reactive transient products, including ROS [46].

Hernando et al. [47] showed that photoprotection against UV-induced damage is characterized by short-term consumption of $\alpha$-T and long-term synthesis of mycosporine-like amino acids (MAAs) in an Antarctic diatom Thalassiosira sp. The UV-B damage/repair ratio during long-term exposure involves the combined action of several endogenous factors within the cell, with MAAs synthesis being the most effective factor. Besides vertical migration and UV screening, copepods rely on photorepair of UV-B-induced DNA damage [48] as shown in species from Patagonia, Argentina [49]. Even more, Obermüller et al. [50] investigated tolerance to UV-R in three amphipod species from the Arctic Kongsfjord, Spitsbergen: the herbivore Gammarellus homari (Fabricius), the strictly carnivore scavenger Anonyx nugax (Phipps) and the detritivore/carnivore Onisimus edwardsi (Krøyer). In both carnivore amphipods elevated sensitivity to experimental UV-R exposure went along with a degradation of tissue carotenoids and MAAs, and a decrease of the enzymatic antioxidant defense (SOD, CAT), which resulted in increased lipid peroxidation in exposed animals. In contrast, the herbivore $G$. homari seems well protected by high concentrations of MAAs absorbed from its algal diet, and no oxidative stress occurred under experimental UV-R exposure. The speciesspecific degree of UV tolerance correlates well with the animals' typical vertical distribution in the water column. Moreover, exposure to UV-R causes apoptosis in developing sea urchin embryos. Embryos of three sea urchin species from different habitats ranging from the Gulf of Maine to the Antarctic showed significant amounts of accumulated DNA damage in the form of cyclobutane pyrimidine dimmers [51].

\subsubsection{Salinity Variations}

In marine waters the most common reported value for salinity is around 35 ups, but it could also vary from 10 to 70 ups as a result of evaporation or precipitation/freshwater influxes [52]. Osmotic stress most often resulting from fluctuating salinities exerts considerable oxidative stress in organism living in the intertidal zone. In aquatic organisms, salinity change causes a variety of physiological responses such as plasma enhanced stress-related hormones, stimulation of energy metabolism, and alteration of electrolyte equilibrium, growth and photosynthesis inhibition in algae $[53,54]$. The stress induced by salinity change has been associated with enhanced ROS generation, causing oxidative damage [55]. Rijstenbil [53] showed that when the diatom Cylindrotheca closterium (Ehrenberg) was exposed to combined UV-B and salt stress (as in immersion) inhibition of growth was measured. Moreover, under these conditions higher activities of SOD, ascorbate peroxidase (APx) and monodehydroascorbate reductase (MDHAR) were found as compared to non-exposed diatoms. Studies employing the macroalga Ulva fasciata (Delile) exposed to salinity stress showed that a long-term exposure to hypo-saline and hypersaline conditions inhibited growth rate and enhanced the availability of antioxidants and the activities of antioxidant enzymes to cope with the oxidative stress generated [56]. Also, a study from Kumar et al. [57] suggested that Gracilaria corticata (J. Agardh) regulates its antioxidant machinery to eliminate ROS under long term salt stress conditions. The ark shell Scapharca broughtonii (Schrenck) and the olive flounder fish Paralichthys olivaceus (Temminck and Schlegel) exposed to changes in salinity showed that the antioxidant enzymes played important roles in reducing oxidative stress $[54,58]$. However, in the shrimp Litopenaeus vannamei (Boone) the experimental findings demonstrated that changes in salinity might be toxic due to a reduction in the antioxidant enzymes activities and the establishment of oxidative stress. Vitamin E (mainly $\alpha$-T) dietary supplementation can be potentially useful to prevent metabolic damage under the tested conditions [55]. Hamer et al. [59] found a close inverse relationship between salinity and susceptibility of DNA to oxidative damage in both, summer and winter, presumably indicating an imbalance of pro-oxidant/antioxidant status in the mussel gills of $M$. galloprovincialis depending on the magnitude of the hyposaline stress. Thus, changes exert on the environmental salinity generate alterations in the oxidative metabolism, including the antioxidant defense systems and the oxidative damage.

\subsection{4. $\mathrm{O}_{2}$ Availability}

Marine invertebrates preserve a high surface to volume ratio and, in contrast to air breathing animals, diffusive $\mathrm{O}_{2}$ uptake over the body surface is an important factor affecting survival. Many aquatic invertebrates are oxyconformers, i.e. $\mathrm{O}_{2}$ consumption varies as a function of the environmental $\mathrm{O}_{2}$ partial pressure $[60,61]$. Since some of these species are highly sensitive to higher environmental $\mathrm{O}_{2}$, they colonize sedimentary, low $\mathrm{O}_{2}$ environments $[62,63]$. However, maintenance of life, in the absence of water, requires a 
complex and finely tuned set of mechanisms working in close coordination [64]. Also, in marine invertebrates from typically low $\mathrm{O}_{2}$ sedimentary habitats, several forms of physiological stress, include critical warming, and lead to functional tissue hypoxia, as ventilation and circulation fail to cover tissue $\mathrm{O}_{2}$ demand [65]. Either directly during the hypoxic state $[66,67]$ or following a hypoxic episode [68$70]$, ROS are released from ubisemiquinone during tissue reoxygenation. Thus, marine ectotherms, which undergo frequent episodes of environmental and physiological hypoxia, are likely to receive elevated levels of ROS formation during or, on recovery from physiological stress. During low tides, tissues like foot and gills are the main targets of the oxidative damage, and as a consequence they may be better protected by the antioxidant enzymes than other tissues. The increase in the antioxidant defenses during physiological states where ROS production might be reduced (anoxia/hypoxia, freezing, hibernation), could be a preparatory mechanism to minimize the potential damage due to the oxidative stress during re-oxygenation (or unfreezing and excitation) when $\mathrm{O}_{2}$ consumption is increased.

Weihe et al. [71] showed that the response to aerial exposure and hypoxia in the oxidative stress parameters differed in intertidal limpet Nacella concinna (Strebel), whereas the antioxidant enzyme activities in sub-littoral specimens responded in the same way to both forms of stress. Intertidal animals respond more rigorously to air exposure than sub-littoral limpets, which maintained shell water $\mathrm{O}_{2}$ pressure at low levels independently of submergence state. The most obvious difference with respect to the antioxidants occurs in the gills. Intertidal limpets reduce SOD activities, whereas in sub-littoral limpets gill SOD activity increases under both forms of stress. These data support the idea that the first strategy of intertidal limpets to control cellular damage is to down regulate metabolism and save energy, including the synthesis of antioxidants, during air exposure/hypoxia [72]. In the stone or false king crab Paralomis granulosa (Hombron and Jacquinot) air exposure alters its oxidant/antioxidant status and triggers antioxidant responses of its enzymes. The oxidative status of $P$. granulosa is also significantly affected by emersion and resubmersion periods. Almost all analyzed tissues showed an increase of antioxidant enzyme activities after air exposure and re-submersion with the highest enzymatic activities found in gills [73].

\subsubsection{Natural Abundance of Chemical Elements}

The toxic effect of heavy metals appears to be related to production of ROS and the resulting unbalanced cellular redox status [4]. Fe is a Fenton reactant which, if not tightly bound to Ft, forms ${ }^{\circ} \mathrm{OH}$ [74]. $\mathrm{Al}$ is the most abundant metal in the earth crust, and although not a transition metal and Fenton reactant, exacerbates Fe catalyzed lipid peroxidation in animal tissues [75]. Likewise, $\mathrm{Zn}$ is not in itself a ROS producing metal, but when highly concentrated it can damage the mitochondria and induce high rates of $\mathrm{O}_{2}^{-}$ release [76]. The prooxidant effect of the non-essential element $\mathrm{Cd}$ is mainly via depletion of GSH and proteinbound sulfhydryl groups, resulting in enhanced production of ROS [77]. The responses on the oxidative metabolism of the organisms to high chemical elements abundance primary depends on the type, concentration, exposure period and excretion efficiency of these elements.

King-George Island (Antarctic) volcanic rock contains between 5 and $7 \% \mathrm{Fe}$ [78], $\mathrm{Al}, \mathrm{Cu}$ and $\mathrm{Zn}$; sediment ablation from glacier melting, eroding the rock surface underneath the glaciers, can lead to metal enrichment through transport of lithogenically derived sediment particles in coastal areas [79, 80]. González and Puntarulo [81] showed that Fe, constantly taken up by the bivalve Laternula elliptica (King), is gradually incorporated into the Ft. The bivalve seems to be successfully adapted to its high $\mathrm{Fe}$ natural environmental conditions, being the antioxidant activity crucial. Even more, formation of NO-Fe complexes (such as mononytrosyl-Fe complexes, MNIC and dinytrosyl-Fe complexes, DNIC) could be one of the mechanisms involved in limiting the damage dependent on $\mathrm{Fe}$ exposure. Chronically high $\mathrm{Fe}$ content effects in the Antarctic species L. elliptica could be adequately controlled by this endogenous mechanism. NO generated in L. elliptica was suggested to contribute to restrict oxidative damage by a close link with $\mathrm{Fe}$ metabolism. Studies in sub-littoral $N$. concinna limpets digestive glands showed high content of heavy metals (Fe, $\mathrm{Al}, \mathrm{Zn}$ ) get from ingested sediments, and this fact was associated with higher rates of ROS formation as compared to intertidal animals. Also, ROS formation was accompanied by significantly higher SOD activity in the sub-littoral group [71]. The differences in the stress response of both limpet sub-groups indicate fundamental differences in the metabolic strategies, which may perhaps have a genetic background [82].

Hydrothermal vents also produce ROS. The abundance of hydrogen sulfide $\left(\mathrm{H}_{2} \mathrm{~S}\right)$ and $\mathrm{O}_{2}$ near vents leads to the oxidation of $\mathrm{H}_{2} \mathrm{~S}$ in seawater and the production of both $\mathrm{O}_{2}$ and sulfur-centered radicals [83]. In particular, electron paramagnetic resonance (EPR) spin-trapping has shown that sulfide oxidation produces $\mathrm{O}_{2}^{-}$[83]. High concentrations of $\mathrm{O}_{2}{ }^{-}$near vents probably lead to $\mathrm{H}_{2} \mathrm{O}_{2}$ production by $\mathrm{O}_{2}{ }^{-}$ dismutation being responsible for subsequent oxidative stress for vent fauna.

Vent worms (Riftia pachyptila Jones), vent clams (Calyptogena magnifica Boss and Turner), and their bacterial symbionts all express SOD and exhibit peroxidase activity [84]. Bebianno et al. [85] reported an interesting study developed in the gills of the mussel Bathymodiolus azoricus (Cosel and Comtet) collected from three contrasting Mid-Atlantic Ridge (MAR) vent fields. These fields have three different zones: Menez-Gwen, Lucky Strike and Rainbow areas. MAR vent sites not only contain high metal concentrations, but are also characterized by a mixture of toxic compounds (metals, $\mathrm{H}_{2} \mathrm{~S}$ and radionuclide) that play an important role in the triggering of antioxidant defenses in marine organisms. Thus, a different profile of the antioxidant defense network was shown to be particularly active in the gills of the mussel isolated from each area. Total Oxyradical 
Scavenging Capacity (TOSC) (towards peroxyl, ${ }^{\circ} \mathrm{OH}$ radicals and $\mathrm{ONOO}^{-}$); cytosolic SOD and GPx activities; and CAT activity, respectively are the main antioxidant mechanisms observed in the mussels depending on the isolation zone. On the other hand, sulphur-amino acids may act as antioxidants in these organisms as well; since $\mathrm{H}_{2} \mathrm{~S}$ is known to react spontaneously with $\mathrm{O}_{2}$ to produce free radicals, such as $\mathrm{O}_{2}^{-}$and sulphur-centered free radicals [83], during sulphide oxidation.

\subsubsection{Pathogen Invasion}

Parasitism influence in ecosystems is often considered to be a tool for regulating the dynamics of invertebrate benthic populations in coastal areas. Higher activity of antioxidant defenses and higher levels of oxidative cellular damage in coral larvae with the dinoflagellate zooxanthellae as compared with no pathogen invasion of the larvae suggest that oxidative stress, originated in the symbionts, is a possible cause of tissue damage in the host under heat stress [86]. Moreover, Neves et al. [87] studied the shrimp Palaemonetes argentinus (Nobili) infected by the isopod Probopyrus ringueleti (Verdi and Schuldt), a gill chamber parasite known for its capacity to cause host metabolic changes, including changes in $\mathrm{O}_{2}$ consumption rates. No significant differences were reported for either CAT or GPx activities; however, SOD activity was significantly reduced in infected shrimp. Even more, Polydora sp., a parasite of the oyster Crassostrea gigas (Thunberg), modifies the behavior and the respiratory physiology of the molluscs probably due to the existence of oxidative stress associated with parasitism characterized by an increase in expression level of the sod1 [88].

\subsection{Anthropogenic Sources}

Regoli et al. [89] and Viarengo et al. [90] have reported that the toxicity of pollutants often depends on their capacity to increase the cellular levels of ROS, since physiological changes in organisms can be related to the effects of toxic chemicals in water that are incorporated and accumulated in tissues and cells. Marine microalgae are particularly promising indicator species for organic and inorganic pollutants because they are typically the most abundant life forms in aquatic environments and occupy the base of the food chain [91]. Oxidative stress is increasingly studied in marine invertebrates and fishes used as sentinel organisms for monitoring pollution in coastal as well as in more remote environments [3, 26, 79, 92-98].

\subsubsection{Deposition of Heavy Metals from Human Activities}

Environmental pollution by metals became extensive as mining and industrial activities increased. Chemical industries, disposal of waste metal, ports, boating activities, agricultural fungicide runoff, domestic garbage dumps, aeolian deposition of atmospheric dust from polluted areas may also bring metals to the marine ecosystem. Algae respond to heavy metals by induction of several antioxidants, including diverse enzymes such as SOD, CAT, GPx and
APx, and the synthesis of low molecular weight compounds such as carotenoids and $\mathrm{GSH}$ [4]. $\mathrm{Cu}$ has been observed to induce metallothionein gene expression in the seagrass Posidonia oceanic (Linnaeus) [99] and in the brown alga Fucus vesiculosus (Linnaeus) [100], and malondialdehyde (MDA) generation in the marine diatom Phaeodactylum tricornutum (Bohlin) [101]. In the marine dinoflagellate Lingulodinium polyedrum (F.Stein), heavy metals cause increased oxidation of proteins and lipids, levels of SOD, APx and $\beta$-carotene; and a decrease in GSH content [102].

The exposure to $\mathrm{Fe}$ of $M$. galloprovincialis [103] or Perna perna (Linnaeus) [104] was reported to lead to a significant increase in MDA levels in digestive glands. In both cases, the induction of phospholipid hydroperoxideGPx activity following the exposure to Fe overload, was described as a potential biomarker of toxicity associated with contaminant exposure. More recently, González et al. [105] reported the effect of in vivo Fe exposure on the bivalve $M$. arenaria suggesting that induction of CAT activity could be operative to limit oxidative damage. In this study, the authors also showed in digestive gland the presence of $\mathrm{NO}$ by EPR, and the ability of this molecule to chelate Fe was proposed as a candidate to inhibit lipid peroxidation.

Giarratano et al. [106] employing the mussel Mytilus edulis chilensis (Hupé) reported that digestive glands were the main target tissue of accumulation of $\mathrm{Fe}$ and $\mathrm{Cu}$, while gill accumulated the highest levels of $\mathrm{Zn}$. Lately, studies in digestive glands from the ribbed mussel Aulacomya atra atra (Molina) showed higher induction of ROS production in samples isolated from animals living in control sites than those from considered impacted sites with high metal concentrations such as $\mathrm{Fe}, \mathrm{Zn}, \mathrm{Cu}, \mathrm{Cd}$ and $\mathrm{Pb}$, suggesting the possibility of some biochemical adaptation of the organisms [107]. On the other hand, Rivera-Ingraham et al. [108] analyzing the effect of trace metals on the endangered limpet Cymbula nigra (da Costa) in the Bay of Algeciras (Strait of Gibraltar) where high trace metals concentrations prevail due to industrial activity [109], showed no significant differences in the content of lipid radical in both digestive gland and gills from the limpets from low and high-polluted areas, reinforcing the idea of the ability of this endangered species to get tolerance to degraded environments. In vertebrates, like the silversides fishes Odontesthes nigricans (Richardson), Lattuca et al. [110] suggested that a higher content of $\mathrm{Fe}$ and $\mathrm{Zn}$ in Varela Bay, as compared to Golondrina Bay (Tierra del Fuego, Argentina), could be responsible for the increase on the lipid radical content and the antioxidant activities observed in the liver of the fish from Varela Bay.

\subsubsection{Presence in Seawater of Hydrocarbons Due to Oil Manufacturing}

The main pollutants dependent on oil activity include polycyclic aromatic hydrocarbons (PAH), alkylphenols, and hydrocarbons [111]. These compounds have low vapor pressures $\left(\log \mathrm{K}_{\mathrm{ow}}>5\right)$; therefore, they are rapidly absorbed by particulate matter and by living organisms [112]. Exposure to several PAH causes oxidative stress in aquatic 
organisms [113, 114]. Liping and Binghui [101] by laboratory studies employing the marine diatom $P$. tricornutum exposed to fluoranthene reported that MDA content of algal cells increased with time and with increasing exposure concentrations. Sureda et al. [115] showed that Glutathion-S-transferase (GST) and cytochrome P4501A activities and metallothionein gene expression in the digestive gland of wild mussels $M$. galloprovincialis were significantly increased one month after an oil spill accident (Don Pedro oil spill at Eivissa Island, Spain), returning to the basal values after six months. Even though, Camus et al. [116] showed that, following exposure to oil-contaminated sediment in an Arctic fjord, PAH were taken up by the bivalve Mya truncata (Linnaeus) and resulted in destabilization of the hemocytes membranes, ROS production was not affected. Moreover, Ansaldo et al. [117] measured lipid hydroperoxides content in digestive gland of the Antarctic limpet $N$. concinna intertidal population exposed up to $1 \%$ diesel and did not observed any significant difference with control animals up to $48 \mathrm{~h}$. In spite of this, after longer time periods $(168 \mathrm{~h})$ animals in contact with $0.05 \%$ diesel showed significantly higher peroxide levels as compared to control animals.

Crude oil does not dissolve to the same extent at low compared with higher temperatures. Such differences in dissolution have important consequences for the bioavailability of oil components at different temperatures [118]. Consequently, the biological adaptation of cold-water organisms, together with the altered oil behavior at low temperature, may affect the typical temperate derived biomarker responses [116]. It has also been shown in the Atlantic cod Gadus morhua (Linnaeus) that the exposure to alkylphenols elevated GR activities and total GSH levels, possibly as a result of the induced oxidative stress; however, nonylphenol depleted the cells from GSH [119]. Regarding the production of RNS, Laffon et al. [120] observed in $M$. galloprovincialis that three months after the Prestige oil spill in the Galician coast, basal NO production by the hemocytes of mussels showed a progressive decrease ending in a stop, both in summer and winter. The loss in NO synthesis capacity paralleled the decrease in DNA stability in gill cells during the same period of study [120].

\subsubsection{Industrial and Urban Wastes}

Wastes from anthropogenic sources include industrial and domestic effluents, storm water runoff, streams, leaching from garbage, solid waste dumps and inputs related to maritime traffic. The major pollutants related to municipal effluents are organic matter, suspended solids, nutrients (nitrogen and phosphorus) and pathogenic microorganisms, while other pollutants such as heavy metals, petroleum and chlorinated hydrocarbons, may also be present [121]. The lack of a sewage treatment plant, the discharges from electronic assembling factories in the area and the intensive maritime traffic were reported as the main sources of pollutants [122, 123]. Oxidative stress biomarkers, measured in gills and digestive gland of the mussel M. edulis chilensis from the Beagle Channel, were successfully used to monitor sites of a coastal marine area with urban influences, showing impact of heavy metals, inorganic nutrients and particulate organic matter [124]. In the mussel M. galloprovincialis different degrees of pollution were related to urban wastes, harbors, agriculture and tourism-derived activities. Moreover, antioxidant activities (CAT, GSH and SOD in gills, and CAT and GR in digestive gland) showed an adaptive response increasing in the polluted areas with significant differences as compared to non-polluted stations [125].

\subsubsection{Pesticides Incidence}

Pesticides are physical, chemical or biological agents intended to kill an undesirable plant or animal pests. It is important to note that most pesticides are synthetic agents, new to the environment and humans and, therefore, their effects on biological systems are poorly predictable. Intense agriculture activity, which can be a source of several toxic elements and compounds found in fertilizers and pesticides may be washed off from soils during heavy rain into the adjacent seawater, and that may cause some toxic effects to organisms inducing oxidative stress via several mechanisms [1]. Organophosphates were introduced as a replacement for the organochlorines and are generally considered non-toxic to plants and algae. However, Schweikert and Burritt [126] studied the impact of Coumaphos, a commonly used organophosphate, on the macrophyte Ulva pertusa (Kjellman). Exposure to Coumaphos (up to $0.01 \mathrm{mg} / \mathrm{l}$ ) caused rapid increases in the levels of protein carbonyls and lipid hydroperoxides (markers of oxidative damage), increases in GSH levels and enhancement of SOD, CAT, GR, APx and GST activities. Recently, Gómez-Mendikute and Cajaraville [127] reported in the mussel $M$. galloprovincialis that hemocytes ROS production was increased in paraquat exposure experiments.

\section{CONCLUSION}

It is widely accepted that both, ROS and RNS, possess injuring potential in living organisms, and that their level should be under strict control to prevent damage. However, the cellular delicate balance could be disturbed leading to perturbations of redox status. The increases in ROS and RNS steady state concentrations could be sensed by specific systems, and regulation mechanisms could be triggered. These responses may be responsible for adaptation of organisms to a broad range of natural environmental stressors [1]. The idea of "preparation to oxidative stress" [128] states that in organisms evolutionarily adapted to transitions between normal and extreme external conditions, an induction of adaptive response would help them to survive at recovery. However, several studies have demonstrated that, for example mussels exposed to different pollutants or stressors, are less tolerant to additional stress exposure and vice versa [129]. A quite different situation is established when the organisms are exposed to anthropogenic factors since there are not "programmed cellular mechanisms" to afford these extreme conditions. 


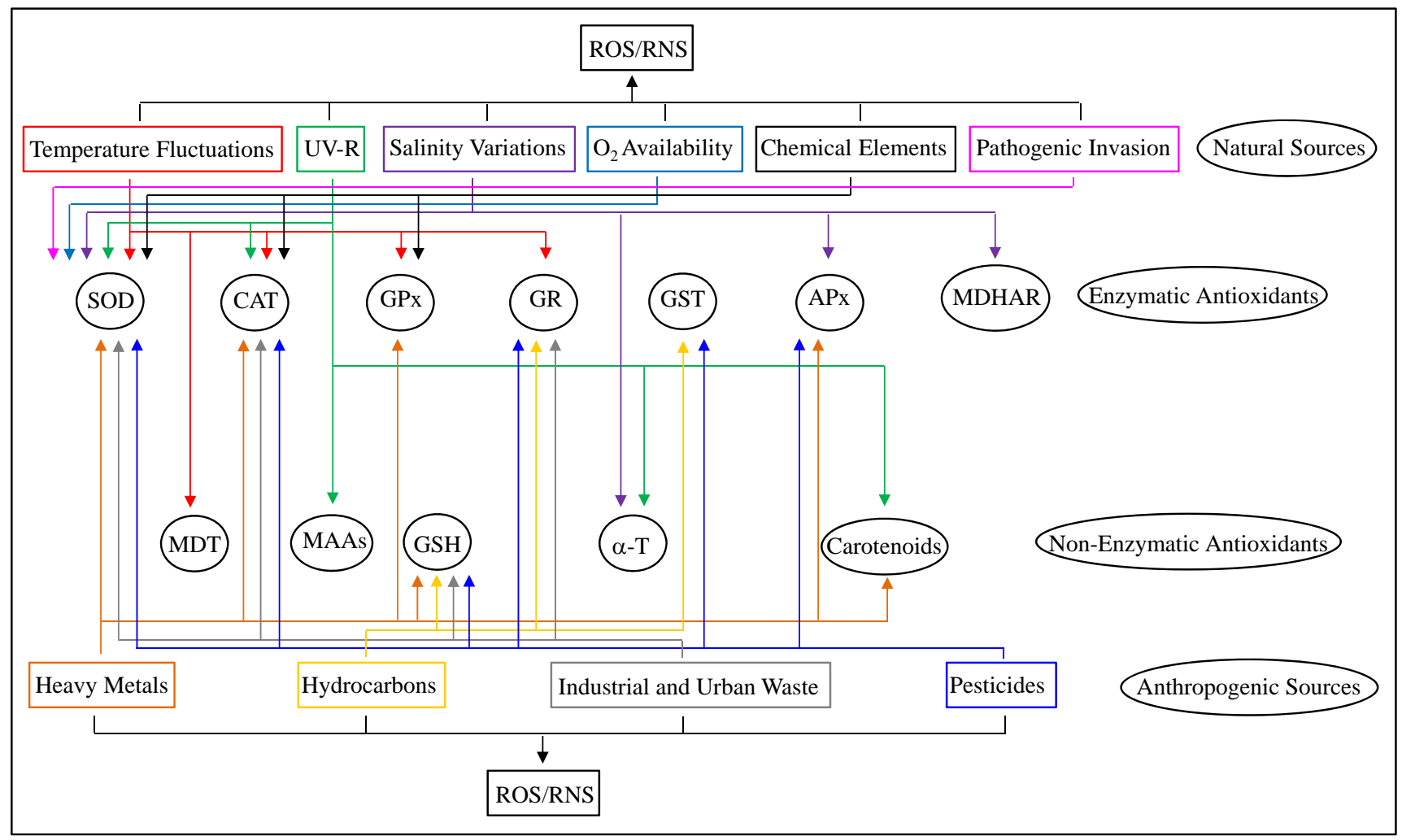

Fig. (4). Brief summary on the effect of the different environmental sources on enzymatic and non-enzymatic antioxidants in the different marine organisms as mentioned in the text. The lines represent effect and not an specific increase on the content or activity.

The data briefly summarized here indicated that the antioxidant network play a key role facing both natural and anthropogenic challenges. The diagram shown in Fig. (4) points out the increase in the activity of the enzymatic antioxidants that was described in a wide array of marine organisms affected by environmental factors.

In an ecological context, marine organisms are exposed to the influence of several abiotic and biotic factors, the effects of multiple factors can greatly differ from simple combinations of single-factor responses [130], and i.e. variables can act in synergistic or antagonistic ways [131]. Thus, effects of environmental factors have to be considered in sampling strategies for monitoring programs to prevent false interpretation of results. A combination of natural stressors and anthropogenic pollution results in several adverse effects occurring under in situ conditions, and their interpretation requires further analysis. Moreover, a relatively new concept of understanding moderate oxidative and nitrosative stresses as a pre-conditioning challenge mean to trigger protection mechanisms to avoid further deeper damage, should be carefully studied in marine organisms. Among the enzymatic antioxidants, this summary suggests that SOD activity seems as the main candidate to act as the antioxidant with more relevance to afford protection, since this activity was increased in almost all the tested conditions. Future research should be responsible for answering this open question.

\section{CONFLICT OF INTEREST}

The authors confirm that this article content has no conflict of interest.

\section{ACKNOWLEDGEMENTS}

This study was supported by grants from the University of Buenos Aires, CONICET and ANPCyT. S.P., G.M. and P.M.G. are career investigators from CONICET.

\section{REFERENCES}

[1] Lushchak VI. Environmentally induced oxidative stress in aquatic animals. Aquat Toxicol 2011; 101: 13-30.

[2] Zhou Q, Zhang J, Fu J, Shi J, Jiang G. Biomonitoring: an appealing tool for assessment of metal pollution in the aquatic ecosystem. Anal Chim Acta 2008; 606: 135-50.

[3] Beyer J. Fish biomarkers in marine pollution monitoring; evaluation and validation in laboratory and field studies. PhD thesis, Norway: University of Bergen 1996.

[4] Pinto E, Sigaud-Kutner TCS, Leitão MAS, Okamoto OK, Morse D, Colepicolo P. Heavy metal-induced oxidative stress in algae. J Phycol 2003; 39: 1008-18.

[5] Lesser MP. Oxidative stress in marine environments. Biochem Physiol Ecol Annu Rev Physiol 2006; 68: 253-78.

[6] González PM, Abele D, Puntarulo S. A kinetic approach to assess oxidative metabolism related features in the bivalve Mya arenaria. Theory Biosci 2012; 131(Pt 4): 253-64. 
[7] Wang J, Pantopoulos K. Regulation of cellular iron metabolism. Biochem J 2011; 434: 365-81.

[8] Harrison PM, Arosio P. The ferritins: molecular properties, iron storage function and cellular regulation. Biochim Biophys Acta 1996; 1275: 161-203.

[9] Chance B, Sies H, Boveris A. Hydroperoxide metabolism in mammalian organs. Physiol Rev 1979; 59: 527-605.

[10] Roginsky VA, Stegmann HB. Ascorbyl radical as natural indicator of oxidative stress: quantitative regularities. Free Radic Biol Med 1994; 17: 93-103.

[11] Galleano M, Aimo L, Puntarulo S. Ascorbyl radical/ascorbate ratio in plasma from iron overloaded rats as oxidative stress indicator. Toxicol Lett 2002; 133: 193-201.

[12] Antunes F, Boveris A, Cadenas E. On the biologic role of the reaction of no with oxidized cytochrome oxidase. Antioxid Redox Signal 2007; 9(Pt10): 1569-80.

[13] $\mathrm{Lu} \mathrm{TH}$, Tseng TJ, Su CC, et al. Arsenic induces reactive oxygen species-caused neuronal cell apoptosis through JNK/ERK-mediated mitochondria-dependent and GRP 78/CHOP-regulated Pathways. Toxicol Lett 2014; 224: 130-40.

[14] Schneppensieper T, Finkler S, Czap A, et al. Tuning the reversible binding of NO to iron(II) aminocarboxylate and related complexes in aqueous solution. Eur J Inorg Chem 2001; 2: 491-501.

[15] Wink DA, Mitchell JB. Chemical biology of nitric oxide: insights into regulatory, cytotoxic, and cytoprotective mechanisms of nitric oxide. Free Radic Biol Med 1998; 25: 434-56.

[16] Knowles RG. Nitric oxide biochemistry. Biochem Soc Trans 1997; 25: 895-901.

[17] Jacklet JW. Nitric oxide signaling in invertebrates. Invert Neurosci 1997; 3: 1-14.

[18] González PM, Abele D, Puntarulo S. Iron and radical content in Mya arenaria. Possible sources of NO generation. Aquat Toxicol 2008; 89:122-28.

[19] Halliwell B. Free radicals and antioxidans. Free radicals, antioxidants, and human disease: curiosity, cause, or consequence? The Lancet 1994; 344: 721-24.

[20] Alexiadis A. Global warming and human activity: a model for studying the potential instability of the carbon dioxide/temperature feedback mechanism. Ecol Mod 2007; 203: 243-56.

[21] Houghton JT, Ding Y, Griggs DJ, et al. Climate change 2001: the scientific basis. UK: Cambridge University Press 2001

[22] Allakhverdiev SI, Kreslavski VD, Klimov VV, Los DA, Carpentier R, Mohanty P. Heat stress: an overview of molecular responses in photosynthesis. Photosynthesis Res 2008; 98: 541-50.

[23] Halliwell B, Gutteridge JMC. Free radicals in biology and medicine. $3^{\text {rd }}$ ed. Oxford: Clarendon Press 1989.

[24] Cossins AR. In: Morris GJ, Clarke A, Eds. Effects of low temperatures on biological membranes. London: Academic Press 1981; pp. 83-106.

[25] Abele D, Puntarulo S. Formation of reactive species and induction of antioxidant defence systems in polar and temperate marine invertebrates and fish. Comp Biochem Physiol A 2004; 138: 40515.

[26] Regoli F, Principato GB, Bertoli E, Nigro M, Orlando E. Biochemical characterization of the antioxidant system in the scallop Adamussium colbecki, a sentinel organism for monitoring the Antarctic environment. Polar Biol 1997; 17: 251-58.

[27] Viarengo A, Canesi L, Martinez PG, Peters LD, Livingstone DR. Prooxidant processes and antioxidant defence systems in the tissues of the Antarctic scallop (Adamussium colbecki) compared with the Mediterranean scallop (Pecten jacobaeus). Comp Biochem Physiol B 1995; 111: 119-26.

[28] Abele D, Heise K, Pörtner HO, Puntarulo S. Temperaturedependence of mitochondrial function and production of reactive oxygen species in the intertidal mud clam Mya arenaria. J Exp Biol 2002; 205(Pt 13): 1831-41.

[29] Davenport J. Meltwater effects on intertidal Antarctic limpets. J Mar Biol Assoc U.K. 2001; 81: 643-49.
[30] Li Y, Gao K, Villafañe VE, Helbling EW. Ocean acidification mediates photosynthetic response to UV radiation and temperature increase in the diatom Phaeodactylum tricornutum. Biogeosci Discuss 2012; 9: 7197-226.

[31] Hazel JR, Williams EE. The role of alterations in membrane lipid composition in enabling physiological adaptations of marine organisms to their physical envirionment. Prog Lipid Res 1990; 29: 167-227.

[32] Woodward B. Dietary vitamin requirements of cultured young fish, with emphasis on quantitative estimates for salmonids. Aquaculture 1994; 124: 133-68.

[33] Yamamoto Y, Fujisawa A, Hara A, Dunlap WC. An unusual vitamin $\mathrm{E}$ constituent provides antioxidant protection in marine organisms adapted to coldwater environments. Proc Natl Acad Sci USA 2001; 98: 13144-48.

[34] Dunlap WC, Fujisawa A, Yamamoto Y, Moylan TJ, Sidell BD. Notothenioid fish, krill and phytoplankton from Antarctica contain a vitamin $\mathrm{E}$ constituent (a-tocomonoenol) functionally associated with cold-water adaptation. Comp Biochem Physiol B 2002; 133: 299-305.

[35] Manney GL, Santee ML, Rex M, et al. Unprecedented Arctic ozone loss in 2011. Nature 2011; 478: 469-75.

[36] Helbling EW, Villafañe VE, Ferrario ME, Hansen OH. Impact of natural ultraviolet radiation on rates of photosynthesis and on specific marine phytoplankton species. Mar Ecol Prog Ser 1992; 80: $89-100$

[37] Heraud P, Beardall J. Changes in chlorophyll fluorescence during exposure of Dunaliella tertiolecta to UV radiation indicate a dynamic interaction between damage and repair processes. Photosynth Res 2000; 63: 123-34.

[38] Gao KS, Guan WC, Helbling EW. Effects of solar ultraviolet radiation on photosynthesis of the marine red tide alga Heterosigma akashiwo (Raphidophyceae). J Photoch Photobio B 2007; 86: 140-48.

[39] Jiang HB, Qiu BS. Inhibition of photosynthesis by UV-B exposure and its repair in the bloom-forming cyanobacterium Microcystis aeruginosa. J Appl Phycol 2011; 23: 691-96.

[40] Grzymski J, Orrico C, Schofield OM. Monochromatic ultraviolet light induced damage to Photosystem II efficiency and carbon fixation in the marine diatom Thalassiosira pseudonana $(3 \mathrm{H})$. Photosynth Res 2001; 68: 181-92.

[41] Xiong FS. Evidence that UV-B tolerance of the photosynthetic apparatus in microalgae is related to the D1-turnover mediated repair cycle in vivo. J Plant Physiol 2001; 158: 285-94.

[42] Gao KS, Li P, Walanabe T, Helbling EW. Combined effects of ultraviolet radiation and temperature on morphology, photosynthesis, and DNA of Arthrospira (Spirulina) platensis (Cyanophyta). J Phycol 2008; 44: 777-86.

[43] Nilawati J, Greenberg BM, Smith REH. Influence of ultraviolet radiation on growth and photosynthesis of two cold ocean diatoms. J Phycol 1997; 33: 215-24.

[44] Barbieri ES, Villafañe VE, Helbling EW. Experimental assessment of UV effects on temperate marine phytoplankton when exposed to variable radiation regimes. Limnol Oceanogr 2002; 47: 1648-55.

[45] Gao KS, Wu YP, Li G, Wu HY, Villafañe VE, Helbling EW. Solar UV radiation drives $\mathrm{CO}_{2}$ fixation in marine phytoplankton: a double-edged sword. Plant Physiol 2007; 144: 54-9.

[46] Mopper K, Kieber DJ. In: De Mora S, Demers S, Vernet M, Eds. The effects of UV radiation in the marine environment. Cambridge, UK: Cambridge University Press 2000; pp. 101-30.

[47] Hernando M, Malanga G, Puntarulo S, Ferreyra G. Non-enzymatic antioxidant photoprotection against potential UVBR-induced damage in an Antarctic diatom (Thalassiosira sp.) Lat Am J Aquat Res 2011; 39(Pt 3): 397-408.

[48] Grad G, Burnett BJ, Williamson CE. UV damage and photoreactivation: timing and age are everything. Photochem Photobiol 2003; 78: 225-7. 
[49] Gonç alves RJ, Villafañe VE, Helbling EW. Photorepair activity and protective compounds in two freshwater zooplankton species (Daphnia menucoensis and Metacyclops mendocinus) from Patagonia, Argentina. Photochem Photobiol Sci 2002; 1: 996-1000.

[50] Obermüller B, Karsten U, Abele D. Response of oxidative stress parameters and sunscreening compounds in Arctic amphipods during experimental exposure to maximal natural UVB radiation. J Exp Mar Ecol 2005; 323: 100-17.

[51] Lesser MP, Kruse VA, Barry TM. Exposure to ultraviolet radiation causes apoptosis in developing sea urchin embryos. J Exp Biol 2003; 206: 4097-103.

[52] Graham LE, Wilcox LW. Algae. New York: Prentice Hall 2000.

[53] Rijstenbil JW. Effects of UVB radiation and salt stress on growth, pigments and antioxidative defence of the marine diatom Cylindrotheca closterium. Mar Ecol Prog Ser 2003; 254: 37-48.

[54] Choi CY, An KW, An MI. Molecular characterization and mRNA expression of glutathione peroxidase and glutathione S-transferase during osmotic stress in olive flounder (Paralichthys olivaceus). Comp Biochem Physiol A 2008; 149: 330-7.

[55] Liu Y, Wang WN, Wang AL, Wang JM, Sun RY. Effects of dietary vitamin E supplementation on antioxidant enzyme activities in Litopenaeus vannamei (Boone, 1931) exposed to acute salinity changes. Aquaculture 2007; 265: 351-8.

[56] Lu I-F, Ming-Shiuan S, Lee T-M. Salinity stress and hydrogen peroxide regulation of antioxidant defense system in Ulva fasciata. Mar Biol 2006; 150: 1-15.

[57] Kumar M, Kumari P, Gupta V, Reddy CRK, Jha B. Biochemical responses of red alga Gracilaria corticata (Gracilariales, Rhodophyta) to salinity induced oxidative stress. J Exp Mar Biol Ecol 2010; 391: 27-34.

[58] An MI, Choi CY. Activity of antioxidant enzymes and physiological responses in ark shell, Scapharca broughtonii, exposed to thermal and osmotic stress: effects on hemolymph and biochemical parameters. Comp Biochem Physiol B 2010; 155: 3442.

[59] Hamer B, Jakšić Ž, Pavičić-Hamer D, et al. Effect of hypoosmotic stress by low salinity acclimation of Mediterranean mussels Mytilus galloprovincialis on biological parameters used for pollution assessment. Aquat Toxicol 2008; 89: 137-51.

[60] Abele D, Grobpietsch H, Pörtner HO. Temporal fluctuations and spatial gradients of environmental $\mathrm{pO}_{2}$, temperature, $\mathrm{H}_{2} \mathrm{O}_{2}$ and $\mathrm{H}_{2} \mathrm{~S}$ in its intertidal habitat trigger enzymatic antioxidant protection in the capitellid worm Heteromastus filiformis. Mar Ecol Prog Ser 1998; 163: 179-91.

[61] Nikinmaa M. Oxygen-dependent cellular functions - why fishes and their aquatic environment are a prime choice of study. Comp Biochem Physiol A 2002; 133: 1-16.

[62] Tschischka K, Abele D, Pörtner HO. Mitochondrial oxyconformity and cold adaptation in the polychaete Nereis pelagica and the bivalve Arctica islandica from Baltic and White Seas. J Exp Biol 2000; 203: 3355-68.

[63] Abele D. Toxic oxygen: the radical life-giver. Nature 2002; 420: 27.

[64] França MB, Panek AD, Eleutherio ECA. Oxidative stress and its effects during dehydration. Comp Biochem Physiol A 2007; 146: 621-31.

[65] Pörtner HO. Climate variations and the physiological basis of temperature dependent biogeography: systemic to molecular hierarchy of thermal tolerance in animals. Comp Biochem Physiol A 2002; 132: 739-61.

[66] Chandel NS, Maltepe E, Goldwasser E, Mathieu CE, Simon MC, Schumacker PT. Mitochondrial reactive oxygen species trigger hypoxia-induced transcription. Proc Natl Acad Sci USA 1998; 95: 11715-20.

[67] Chandel NS, Schumacker PT. Cellular oxygen sensing by mitochondria: old questions, new insight. J Applied Physiol 2000; 88: 1880-9.

[68] Boveris A, Chance B. The mitochondrial generation of hydrogen peroxide. Biochem J 1973; 134: 707-16.
[69] Loschen G, Azzi A, Flohe' L. Mitochondrial $\mathrm{H}_{2} \mathrm{O}_{2}$ formation: relationship with energy conservation. FEBS Lett 1973; 33: 84-8.

[70] Duranteau J, Chandel NS, Kulisz A, Shao Z, Schumacker PT. Intracellular signaling by reactive oxygen species during hypoxia in cardiomyocytes. J Biol Chem 1998; 273: 11619-24.

[71] Weihe E, Kriews M, Abele D. Differences in heavy metal concentrations and in the response of the antioxidant system to hypoxia and air exposure in the Antarctic limpet Nacella concinna. Mar Environ Res 2010; 69(Pt 3): 127-35.

[72] Weihe E, Abele D. Differences in the physiological response of inter- and subtidal Antarctic limpets Nacella concinna to aerial exposure. Aquat Biol 2008; 4: 155-66.

[73] Romero MC, Tapella F, Sotelano MPa, Ansaldo M, Lovrich GA. Oxidative stress in the subantarctic false king crab Paralomis granulosa during air exposure and subsequent re-submersion. Aquaculture 2011; 319: 205-10.

[74] Puntarulo S, Cederbaum AI. Comparison of the ability of the ferric complexes to catalyze microsomal chemiluminescence, lipid peroxidation and hydroxyl radical generation. Arch Biochem Biophys 1988; 264: 482-91.

[75] Quinlan GJ, Halliwell B, Moorhouse CP, Gutteridge JMC. Action of lead (II) and aluminium (III) ions on ironstimulated lipid peroxidation in liposomes, erythrocytes and rat liver microsomal fractions. Biochim Biophys Acta 1988; 962: 196-200.

[76] Halliwell B, Gutteridge JMC. Free Radicals in Biology and Medicine. $4^{\text {th }}$ ed. London: Oxford: Oxford University Press; 2007.

[77] Stohs SJ, Bagghi D. Mechanisms in the toxicity of metal ions. Free Rad Biol Med 1995; 18: 321-36.

[78] Tatur A, Valle R, Barczuk A. In: Polish Polar Studies, Proceedings of XXVI Polar Symposium 1999; pp. 305-21.

[79] Ahn I-Y, Lee SH, Kim KY, Shim JH, Kim D-Y. Baseline heavy metal concentrations in the Antarctic clam Laternula elliptica in Maxwell Bay, King George Island, Antarctica. Mar Pollut Bull 1996; 32: 592-8.

[80] Dierssen HM, Smith RC, Vernet M. Glacial meltwater dynamics in coastal waters west of Antarctic Peninsula. Proc Nat Acad Sci 2002; 99: 1790-5.

[81] González PM, Puntarulo S. Iron and nitrosative metabolism in the Antarctic mollusk Laternula elliptica. Comp Biochem Physiol C 2011; 153: 243-50.

[82] de Aranzamendi MC, Sahade R, Tatián M, Chiappero MB. Genetic differentiation between morphotypes in the Antarctic limpet Nacella concinna as revealed by inter-simple sequence repeat markers. Mar Biol 2008; 154: 875-85.

[83] Tapley DW, Buettner GR, Shick JM. Free radicals and chemiluminescence as products of the spontaneous oxidation of sulfide in seawater, and their biological implications. Biol Bull 1999; 196: 52-6.

[84] Blum J, Fridovich I. Enzymatic defenses against oxygen toxicity in the hydrothermal vent animals Riftia pachyptila and Calyptogena magnifica. Arch Biochem Biophys 1984; 228: 617-20.

[85] Bebianno MJ, Company R, Serafim A, Camus L, Cosson RP, FialaMédoni A. Antioxidant systems and lipid peroxidation in Bathymodiolus azoricus from Mid-Atlantic ridge hydrothermal vent fields. Aquat Toxicol 2005; 75: 354-73.

[86] Yakovleva IM, Baird AH, Yamamoto HH, Bhagooli R, Nonaka M, Hidaka M. Algal symbionts increase oxidative damage and death in coral larvae at high temperatures. Mar Ecol Prog Ser 2009; 378: 105-12.

[87] Neves CA, Santos EA, Bainy ACD. Reduced superoxide dismutase activity in Palaemonetes argentinus (Decapoda, Palemonidae) infected by Probopyrus ringueleti (Isopoda, Bopyridae). Dis Aquat Org 2000; 39: 155-8

[88] Chambon C, Legeay A, Durrieu G, Gonzalez P, Ciret P, Massabuau JC. Influence of the parasite worm Polydora sp. on the behavior of the oyster Crassostrea gigas: a study of the respiratory impact and associated oxidative stress. Mar Biol 2007; 152: 32938. 
[89] Regoli F, Gorbi S, Frenzilli G, et al. Oxidative stress in ecotoxicology: from the analysis of individual antioxidants to a more integrated approach. Mar Environ Res 2002; 54: 419-23.

[90] Viarengo A, Lowe D, Bolognesi C, Fabbri E, Koehler A. The use of biomarkers in biomonitoring: a 2-tier approach assessing the level of pollutant-induced stress syndrome in sentinel organisms. Comp Biochem Physiol C 2007; 146: 281-300.

[91] Torres MA, Barros MP, Campos SCG, et al. Biochemical biomarkers in algae and marine pollution: A review. Ecotoxicol Environ Saf 2008; 71: 1-15.

[92] Viarengo A, Canesi L, Pertica M, Poli G, Moore MN, Orunesu M. Heavy metal effects on lipid peroxidation in the tissues of Mytilus galloprovincialis. Lam Comp Biochem Physiol C 1990; 97: 37-42.

[93] Kirchin MA, Moore MN, Dean RT, Winston GW. The role of oxyradicals in intracellular proteolysis and toxicity in mussels. Mar Environ Res 1992; 34: 315-20.

[94] Regoli F. Lysosomal responses as a sensitive stress index in biomonitoring heavy metal pollution. Mar Ecol Prog Ser 1992; 84: 63-9.

[95] Palace VP, Klaverkamp JF. Variation of hepatic enzymes in three species of freshwater fish from precambrian shield lakes and the effect of cadmium exposure. Comp Biochem Physiol C 1993; 104: $147-54$.

[96] Pellerin-Massicote J. Oxidative process as indicators of chemical stress in marine bivalves. J Aquat Ecosyst Health 1994; 3(Pt 2): 101-11.

[97] Regoli F, Nigro M, Orlando E. Lysosomal and antioxidant responses to metals in the Antarctic scallop Adamussium colbecki. Aquat Toxicol 1998; 40: 375-92.

[98] Angel DL, Fiedler U, Eden N, Kress N, Adelung D, Herut B. Catalase activity in macro and micro-organisms as an indicator of biotic stress in coastal waters of the eastern Mediterranean Sea. Helgol Mar Res 1999; 53: 209-18.

[99] Giordani T, Natali L, Maserti BE, Taddei S, Cavallini A. Characterization and expression of DNA sequences encoding putative type-II metallothioneins in the seagrass Posidonia Oceanica. Plant Physiol 2000; 123: 1571-81.

[100] Morris CA, Nicolaus B, Sampson V, Harwood JL, Kille P. Identification and characterization of a recombinant metallothionein protein from a marine alga, (Fucus vesiculosus). Biochem J 1999; 338: 553-60.

[101] Liping W, Binghui Z. Toxic effects of fluoranthene and copper on marine diatom Phaeodactylum tricornutum. J Environ Sci 2008; 20: $1363-72$

[102] Okamoto KO, Pinto E, Latorre LR, Bechara EJH, Colepicolo P. Antioxidant modulation in response to metal-induced oxidative stress in algal chloroplasts. Arch Environ Contam Toxicol 2001; 40: 18-24.

[103] Viarengo A, Burlando B, Cavaletto M, Marchi B, Ponzano E, Blasco J. Role of metallothionein against oxidative stress in the mussel Mytilus galloprovincialis. Am J Physiol Regulatory Integrative Comp Physiol 1999; 277: 1612-9.

[104] Alves de Almeida E, Miyamoto S, Bainy ACD, Medeiros MHG, Di Mascio P. Protective effects of phospholipid hydroperoxide glutathione peroxidase (PHGPx) against lipid peroxidation in mussels Perna perna exposed to different metals. Mar Pollut Bull 2004; 49: 386-92.

[105] González PM, Abele D, Puntarulo S. Exposure to excess dissolved iron in vivo affects oxidative status in the bivalve Mya arenaria. Comp Biochem Physiol C 2010; 152: 167-74.

[106] Giarratano E, Duarte CA, Amin OA. Biomarkers and heavy metal bioaccumulation in mussels transplanted to coastal waters of the Beagle Channel. Ecotoxicol Environ Saf 2010; 73: 270-79.

[107] Giarratano E, Gil MN, Malanga G. Assessment of antioxidant responses and trace metal accumulation by digestive gland of ribbed mussel Aulacomya atra atra from Northern Patagonia. Ecotoxicol Environ Saf 2013; 92: 39-50.

[108] Rivera-Ingraham GA, Malanga G, Puntarulo S, et al. Antioxidant defenses and trace metal bioaccumulation capacity of Cymbula nigra (Gastropoda: Patellidae). Water Air Soil Pollut 2013; 224: 1458-66.
[109] Morillo J, Usero J. Trace metal bioavailability in the waters of two different habitats in Spain: Huelva estuary and Algeciras Bay. Ecotoxicol Environ Saf 2008; 71(3): 851-9.

[110] Lattuca ME, Pérez AF, Giarratano E, Malanga G. Baseline levels of biomarkers of oxidative damage in Odontesthes nigricans (Pisces, Atherinopsidae) from two coastal areas of the Beagle Channel, Argentina. Rev Chil His Nat 2013; 86: 453-64.

[111] Sturve J, Hasselberg L, Fälth H, Celander M, Förlin L. Effects of North Sea oil and alkylphenols on biomarker responses in juvenile Atlantic cod (Gadus morhua). Aquat Toxicol 2006; 78: 73-8.

[112] Nielsen T, Siigur K, Helweg C, Jorgensen O, Hansen PE, Kirso U. Sorption of polycyclic aromatic compounds to humic acid as studied by high performance liquid chromatography. Environ Sci Technol 1997; 31: 1102-8.

[113] Winston GW, Di Giulio RT. Prooxidant and antioxidant mechanisms in aquatic organisms. Aquat Toxicol 1991; 19(2): 13761.

[114] Livingstone DR. Contaminant-stimulated reactive oxygen species production and oxidative damage in aquatic organisms. Mar Pollut Bull 2001; 42: 656-66.

[115] Sureda A, Box A, Tejada S, Blanco A, Caixach J, Deudero S Biochemical responses of Mytilus galloprovincialis as biomarkers of acute environmental pollution caused by the Don Pedro oil spill (Eivissa Island, Spain). Aquat Toxicol 2011; 101: 540-9.

[116] Camus L, Birkely SR, Jones MB, et al. Biomarker responses and PAH uptake in Mya truncata following exposure to oilcontaminated sediment in an Arctic fjord (Svalbard). Sci Total Environ 2003; 308: 221-34.

[117] Ansaldo M, Najle R, Luquet CM. Oxidative stress generated by diesel seawater contamination in the digestive gland of the Antarctic limpet Nacella concinna. Mar Environ Res 2005; 59 (Pt 4): 381-90.

[118] Neff JM. Polycyclic Aromatic Hydrocarbons in the Aquatic Environment. London: Applied Science Publishers Ltd 1979.

[119] Hasselberg L, Meier S, Svardal A. Effects of alkylphenols on redox status in first spawning Atlantic cod (Gadus morhua). Aquat Toxicol 2004; 9: 95-105.

[120] Laffon B, Rábade T, Pásaro E, Méndez J. Monitoring of the impact of Prestige oil spill on Mytilus galloprovincialis from Galicia coast. Env Int 2006, 32: 342-8

[121] Moore JK, Doney SC, Lindsay K. Upper ocean ecosystem dynamics and iron cycling in a global three dimensional model. Global Biogeochem Cy 2004, 18(4 Pt GB4028): 1-21.

[122] Amin O, Ferrer L, Marcovecchio J. Heavy metal concentrations in littoral sediments from the Beagle Channel, Tierra del Fuego, Argentina. Environ Monit Assess 1996; 4: 219-31.

[123] Esteves JL, Commendatore M, Nievas M, Paletto MM, Amin O. Hydrocarbon pollution in coastal sediments of Tierra del Fuego Island, Patagonia Argentina. Mar Pollut Bull 2006; 52: 572-97.

[124] Duarte CA, Giarratano E, Amin OA, Comoglio LI. Heavy metal concentrations and biomarkers of oxidative stress in native mussels (Mytilus edulis chilensis) from Beagle Channel coast (Tierra del Fuego, Argentina). Mar Pollut Bull 2011; 62: 1895-904.

[125] Box A, Sureda A, Galgani F, Pons A, Deudero S. Assessment of environmental pollution at Balearic Islands applying oxidative stress biomarkers in the mussel Mytilus galloprovincialis. Comp Biochem Physiol C. 2007; 146: 531-9.

[126] Schweikert K, Burritt DJ. The organophosphate insecticide Coumaphos induces oxidative stress and increases antioxidant and detoxification defences in the green macroalgae Ulva pertusa. Aquat Toxicol 2012; 122-123: 86-92.

[127] Gómez-Mendikute A, Cajaraville MP. Comparative effects of cadmium, copper, paraquat and benzo[a]pyrene on the actin cytoskeleton and production of reactive oxygen species (ROS) in mussel haemocytes. Toxicol In Vitro 2003; 17: 539-46.

[128] Hermes-Lima M, Storey JM, Storey KB. Antioxidant defenses and metabolic depression. The hypothesis of preparation for oxidative stress in land snails. Comp Biochem Physiol B 1998; 120: 437-48.

[129] Thomas RE, Harris PM, Rice SD. Survival in air of Mytilus trossulus following long-term exposure to spilled Exxon Valdez crude oil in Prince Williams sound. Comp Biochem Physiol C 1999; 122: 147-52. 
[130] Christensen MR, Graham MD, Vinebrooke RD, Findlay DL, Paterson MJ, Turner MA. Multiple anthropogenic stressors cause ecological surprises in boreal lakes. Global Change Biol 2006; 12: 2316-22.
[131] Dunne RP. Synergy or antagonism - interactions between stressors on coral reefs. Coral Reefs 2010; 29: 145-52.

Received: June 06, 2014

Revised: February 02, 2015

Accepted: February 03, 2015

(c) González et al.; Licensee Bentham Open.

This is an open access article licensed under the terms of the Creative Commons Attribution Non-Commercial License (http://creativecommons.org/licenses/bync/3.0/), which permits unrestricted, non-commercial use, distribution and reproduction in any medium, provided the work is properly cited. 